\title{
Comparison of the
}

\section{molecular interactions of}

\section{two antagonists, MEN16132} or icatibant, at the human kinin $B_{2}$ receptor

\author{
S Meini ${ }^{1}$, F Bellucci ${ }^{1}, \mathrm{C}_{\text {Catalani }}{ }^{1}, \mathrm{P} \mathrm{Cucchi}^{1}, \mathrm{~A} \mathrm{Giolitti}^{2}$, S Giuliani ${ }^{1}$, \\ L Quartara $^{3}$, L Rotondaro ${ }^{4}$, S Zappitelli ${ }^{4}$ and CA Maggi ${ }^{1}$
}

Departments of ${ }^{1}$ Pharmacology, ${ }^{2}$ Drug Design, and ${ }^{3}$ Chemistry, Menarini Ricerche, Florence, and

${ }^{4}$ Deparment of Biotechnology, Menarini Biotech, Rome, Italy

\section{Correspondence}

Stefania Meini, Department of Pharmacology, Menarini Ricerche, via Rismondo 12A, 50131 Florence, Italy. E-mail: smeini@menarini-ricerche.it

\section{Keywords}

antagonist interaction; binding; bradykinin; $\mathrm{G}$ protein-coupled receptors; icatibant; kinin $\mathrm{B}_{2}$ receptor; MEN16132; mutagenesis; reversibility

\section{Received}

4 June 2010

Revised

22 September 2010

Accepted

28 October 2010

\section{BACKGROUND AND PURPOSE}

Icatibant is a well-known kinin $B_{2}$ receptor antagonist currently used for angiooedema attacks. MEN16132 is a non-peptide $B_{2}$ receptor antagonist, more potent and long lasting than icatibant in different models. Here we studied the reasons for these differences between the two antagonists.

\section{EXPERIMENTAL APPROACH}

Rate of reversibility (over about $3 \mathrm{~h}$ ) of the functional receptor blockade exerted by the antagonists was compared (inositol phosphates accumulation assay) in $\mathrm{CHO}$ cells expressing the human $\mathrm{B}_{2}$ receptor and in human synovial cells. Antagonist pretreated cells were washed with medium and the time taken to restore bradykinin (BK) response measured. Antagonist affinity was measured by radioligand binding to wild type and mutated $B_{2}$ receptors.

\section{KEY RESULTS}

Recovery of BK-induced responses was slower in cells pretreated with MEN16132 than in those treated with icatibant. The affinity of icatibant (for the $\left[{ }^{3} \mathrm{H}\right]-\mathrm{BK}$ or the $\mathrm{B}_{2}$ receptor antagonist $\left[{ }^{3} \mathrm{H}\right]-\mathrm{MEN} 11270$ binding site) was compared to that of MEN16132 using a panel of point-mutated receptors with mutations located at the transmembrane regions of the $B_{2}$ receptor, previously shown to decrease MEN16132 high affinity interaction. No consistent decrease of icatibant affinity was observed. From the different affinity of MEN16132 derivatives at wild type and W86A (transmembrane 2 region) receptors, and by evaluating its antagonist profile at the D266A/D284A double mutant receptor, a model of the MEN16132-B M $_{2}$ (eceptor complex is proposed.

\section{CONCLUSIONS AND IMPLICATIONS}

MEN16132 dissociated from the $B_{2}$ receptor compartment more slowly than icatibant and interacted at a deeper level in transmembrane regions of the receptor.

\section{Abbreviations}

BK, bradykinin; DMSO, dimethyl sulfoxide; GPCR, G protein-coupled receptor; IP, inositol phosphate; PBS, phosphate buffered saline; TM, transmembrane

\section{Introduction}

Bradykinin (BK, Arg-Pro-Pro-Gly-Phe-Ser-Pro-Phe-Arg) is a small peptide ubiquitously formed by the action of kallikreins on circulating kininogens (Regoli and Barabé, 1980). Once formed it acts on the $\mathrm{B}_{2}$ receptor (receptor nomenclature follows Alexander et al., 2009), a transmembrane (TM) $\mathrm{G}$ protein-coupled receptor (GPCR), which has been 
pharmacologically characterized and molecularly cloned. Activation of the $B_{2}$ receptor leads to $G_{q / 11}$ protein coupling, which triggers phospholipase $\mathrm{C}$ with consequent inositol 3-phosphate and diacylglycerol formation, and release of intracellular calcium, and all the consequently activated intracellular pathways (Leeb-Lundberg et al., 2005 for review).

The participation of BK in inflammation and pain, extensively shown in different models, drove the search to discover selective kinin $B_{2}$ receptor antagonists, of peptide structure first and then non-peptide. Icatibant (formerly named Hoe140, D-Arg-[Hyp ${ }^{3}$, Thi ${ }^{5}$, D-Tic $\left.{ }^{7}, \mathrm{Oic}^{8}\right]$-BK, Hock et al., 1991; Wirth et al., 1991) is now the most investigated $B_{2}$ receptor antagonist, and the only one to reach the market as therapy, for hereditary angiooedema attacks (Firazyr $®$ ). Its structure was designed to confer metabolic resistance to peptidases and rigidity at the $\mathrm{C}$-terminal portion of the peptide backbone, features that have been reported to contribute to its metabolic resistance and prolonged duration of action in different animal models (Wirth et al., 1991; Bond et al., 1992; Legat et al., 1994). Following this, several non-peptide $B_{2}$ receptor antagonists have been synthesised (Dziadulewicz, 2005; Fincham et al., 2009). MEN16132 is a non-peptide antagonist selective for the $\mathrm{B}_{2}$ receptor. It displays a remarkably high affinity and antagonist potency in different species (human, guinea pig, mouse, rat, rabbit and pig) as shown by radioligand binding (using tritiated $\mathrm{BK}$ as radioligand) and functional in vitro assays [inositol phosphate (IP) accumulation and smooth muscle contractility] (Cucchi et al., 2005; Meini et al., 2007; 2009; 2010). Furthermore, in preclinical models of inflammation and pain, MEN16132 was effective and long lasting in blocking both exogenously administered and endogenously formed BK (Valenti et al., 2005; 2008; Cialdai et al., 2009). In all these models the pharmacological properties of MEN16132 were compared with those of icatibant, and despite their comparable high affinity for the $\mathrm{B}_{2}$ receptor, MEN16132 displayed a significantly greater antagonistic potency and longer duration of action both in vitro and in vivo.

The present investigation deals with the reasons for these clear-cut and constant differences between MEN16132 and icatibant. First, the reversibility of antagonist action in blocking $\mathrm{B}_{2}$ receptors was compared through functional experiments (IP accumulation assay) both at the recombinant human $\mathrm{B}_{2}$ receptor (stably expressed in $\mathrm{CHO}$ cells) and at the native $B_{2}$ receptor (endogenously expressed in human fibroblast-like synovial cells). These two cell assays were chosen in order to gain information on the antagonistic interaction with the human $\mathrm{B}_{2}$ receptor: $\mathrm{CHO}$ cells as the system used to investigate the antagonistic interaction mode, synovial cells as a likely therapeutic cell target (MEN16132 is currently in phase II as intraarticular treatment for osteoarthritis, and synovitis is one of the main aspect of this disease). Then, through radioligand binding experiments the affinities of MEN16132 and icatibant were compared, using a panel of point-mutated receptors, with mutated amino acid residues located at TM level of the human $\mathrm{B}_{2}$ receptor sequence. Last, in order to propose and refine a docking model of MEN16132 with the human $\mathrm{B}_{2}$ receptor, its affinity outline, in comparison with a series of modified derivatives, and its antagonist profile were investigated at some mutated receptors.

Overall, our data indicate that MEN16132 is more potent than icatibant in regard to its slower reversibility from the $B_{2}$ receptor compartment. This is, in turn, due to a ligandreceptor interaction located in the TM portion of the receptor protein, and involving residues implied in receptor activation.

\section{Methods}

Cells

Dihydrofolate reductase (DHFR)-deficient $\mathrm{CHO}$ cell line $\mathrm{CHO}$ DUKX-B11 stably expressing the wild type or mutated human kinin $\mathrm{B}_{2}$ receptors (Bellucci et al., 2003; Meini et al., 2004) were cultured in Iscove's modified Dulbecco's medium (IMDM, Cat. No. I3390, Sigma-Aldrich, Dorset, UK), containing $10 \%$ dialysed foetal bovine serum (FBS, Cat. No. SH30079.03, Hyclone, UT, USA), 2 mM L-glutamine (Gln, Cat. No. G7513, Sigma-Aldrich, Dorset, UK) and 1\% of penicillin and streptomycin (Cat. No. P4333, Sigma-Aldrich). The cells were subcultured by using $0.25 \%$ trypsin and $1 \mathrm{mM}$ EDTA to detach them, and then cultured in $175 \mathrm{~cm}^{2}$ flasks and maintained in a humidified atmosphere at $37^{\circ} \mathrm{C}$ with $5 \%$ $\mathrm{CO}_{2}$. Cells at confluence were used to prepare membranes (see below) for radioligand binding experiments, or seeded in $75 \mathrm{~cm}^{2}$ flasks $\left(7000\right.$ cells $\cdot \mathrm{cm}^{-2}$ ) for cell culture maintenance and membrane preparation, and in 24-well plates (150000 cells $\cdot \mathrm{cm}^{-2}$ ) for functional experiments.

Human fibroblast-like synoviocytes derived from normal synovial tissue were purchased as frozen vials (catalogue no. 408-05a: lots no. 1828 and 1798) from European Collection of Cell Cultures (ECACC, Salisbury, UK). Cells were handled as recommended by the producer: the seeding density for attachment was 7000 cells $\cdot \mathrm{cm}^{-2}$ on plastic wells, and the culture medium was Synoviocyte Growth Medium (ECACC, catalogue no. 06091516, CAI no. 415-500), with glutamine $(2 \mathrm{mM})$, penicillin $\left(50 \mu \mathrm{g} \cdot \mathrm{mL}^{-1}\right)$, streptomycin $\left(50 \mu \mathrm{g} \cdot \mathrm{mL}^{-1}\right)$ and amphotericin B $\left(15 \mu \mathrm{g} \cdot \mathrm{mL}^{-1}\right)$. When cells reached $90 \%$ of confluency they were split by using a subculture reagent kit according to the manufacturer's instructions (Lonza, catalogue no. CC3233, Walkersville, MD, USA) and seeded in $75 \mathrm{~cm}^{2}$ flasks $\left(7000\right.$ cells $\cdot \mathrm{cm}^{-2}$ ) for cell culture maintenance and membrane preparation, and in 24-well plates (25000 cells $\cdot \mathrm{cm}^{-2}$ ) for functional experiments. Cells were used between 2 and 10 passages.

\section{Measurement of IP accumulation}

Cells were grown in 24-well tissue culture plates and labelled with myo- $\left[{ }^{3} \mathrm{H}\right]$ inositol $\left(0.5 \mathrm{~mL} \cdot \mathrm{well}^{-1}, 1 \mu \mathrm{Ci} \cdot \mathrm{mL}^{-1}\right)$ in Iscove's modified Dulbecco's medium and Ham's F12 medium (1:1) containing 1\% FBS and L-glutamine ( $2 \mathrm{mM})$. After $24 \mathrm{~h}$ (CHO cells) or $48 \mathrm{~h}$ (human synoviocytes) the medium was removed and cells were preincubated for $15 \mathrm{~min}\left(37^{\circ} \mathrm{C}\right)$ with antagonists at the indicated concentration in the stimulation buffer: phosphate buffered saline (PBS) without $\mathrm{Ca}^{2+}$ and $\mathrm{Mg}^{2+}$ $(135 \mathrm{mM})$, with HEPES $(20 \mathrm{mM}), \mathrm{CaCl}_{2}(2 \mathrm{mM}), \mathrm{MgSO}_{4}$ $(1.2 \mathrm{mM})$, EGTA $(1 \mathrm{mM})$, glucose $(11.1 \mathrm{mM})$, captopril $(10 \mu \mathrm{M})$, bovine serum albumin (BSA) $(0.05 \%), \mathrm{LiCl}(25 \mathrm{mM})$. In reversibility experiments $\mathrm{BK}(3 \mathrm{nM})$ was added after different times during which the medium was totally renewed, both in vehicle (control) and antagonist-treated cells, and reaction stopped after $60 \mathrm{~min}$ agonist incubation period. In 
the experiments in which stimulation was performed with the non-peptide $B_{2}$ receptor agonist FR190997, an incubation period of $30 \mathrm{~min}$ was used as previously described (Bellucci et al., 2003; 2004). Total IP levels were determined as previously described (Bellucci et al., 2003). Determinations were performed in triplicate.

\section{Membrane preparation}

Cells at confluence were washed out of the medium by PBS without calcium and magnesium and harvested by incubation at $37^{\circ} \mathrm{C}$ with Hanks Buffered Salt Solution (HBSS, $\mathrm{pH}$ 7.4) HEPES (10 mM), EDTA $1 \mathrm{mM}$, and a cocktail of peptidase inhibitors: 1,10 phenanthroline $(1 \mathrm{mM})$, EGTA $(1 \mathrm{mM})$, captopril, leupeptin, soybean trypsin inhibitor, DL-2-mercaptomethyl-3-guanidoethylthiopropanoic acid (MERGETPA; $1 \mu \mathrm{M}$ each), chymostatin $(3.3 \mu \mathrm{M})$, phenylmethyl-sulphonyl fluoride $(0.1 \mathrm{mM})$ and bacitracin $\left(140 \mu \mathrm{g} \cdot \mathrm{mL}^{-1}\right)$. Cells were then washed in N-tris [hydroxymethyl]methyl-2-aminoethanesulphonic acid (TES, $10 \mathrm{mM}, \mathrm{pH} 7.4$, at $4^{\circ} \mathrm{C}$ ), containing the cocktail of peptidase inhibitors described above and homogenized with a Polytron (PT 3000, Kinematica), set at 15000 r.p.m. for 30 s. The homogenate was centrifuged at $45000 \times g$ for $45 \mathrm{~min}\left(4^{\circ} \mathrm{C}\right)$. The protein concentration was determined by the method of Bradford using a Bio-Rad kit and BSA as reference standard. The pellet was resuspended to obtain $7.5 \mathrm{mg} \cdot \mathrm{mL}^{-1}$ membrane protein concentration and frozen in $1 \mathrm{~mL}$ aliquots by immersion in liquid nitrogen, and then stored at $-80^{\circ} \mathrm{C}$ until use.

Immediately prior to use, frozen membrane aliquots were thawed in binding buffer (see below) and mixed to give a homogeneous membrane suspension.

\section{Radioligand binding}

The buffer used for binding experiments was TES (10 mM, pH 7.4) containing 1,10- phenanthroline $(1 \mathrm{mM})$, bacitracin $\left(140 \mu \mathrm{g} \cdot \mathrm{mL}^{-1}\right)$, and BSA $\left(1 \mathrm{~g} \cdot \mathrm{L}^{-1}\right)$. Binding assay was performed in a final volume of $0.5 \mathrm{~mL}$. An incubation time of $60 \mathrm{~min}$ at room temperature was used. Competition binding studies were carried out with a radioligand concentration comparable with the calculated $\mathrm{K}_{\mathrm{d}}$ value $\left(0.1-0.2 \mathrm{nM}\left[{ }^{3} \mathrm{H}\right]-\mathrm{BK}\right.$ or $\left.\left[{ }^{3} \mathrm{H}\right]-\mathrm{MEN11270}\right)$, which did not differ among the studied receptors. At this concentration, bound ligand was less than $10 \%$ of the total added radioligand concentration. In preliminary experiments we observed that the specific binding of each radioligand was directly proportional to membrane concentration. A membrane protein concentration between 90 and $200 \mu \mathrm{g} \cdot \mathrm{mL}^{-1}$ was used for each receptor to obtain a signal of $1500-3000 \mathrm{dpm} \cdot$ assay $^{-1}$ of specific binding. Non-specific binding was defined as the amount of labelled radioligand bound in the presence of $1 \mu \mathrm{M}$ of unlabelled appropriate ligand. Under each selected condition the specific binding represented approximately $70-80 \%$ of the total binding. Maximal receptor density $\left(\mathrm{B}_{\max }\right)$ was evaluated by using three different saturating concentrations of $\left[{ }^{3} \mathrm{H}\right]-\mathrm{BK}(5,10$ and $20 \mathrm{nM})$.

Competing ligands were tested in a wide range of concentrations $(1 \mathrm{pM}-1 \mu \mathrm{M})$. Each experiment was performed in duplicate. Experiments were designed to minimize experimental differences, that is, different compounds were simultaneously tested on different cell systems or receptors (wild type and mutants or $\mathrm{CHO}$ and synovial cell membranes). Competing ligands were placed into 96-well plates by the aid of a liquid handling automation system (Multiprobe II, PerkinElmer, Waltham, MA, USA). All incubations were terminated by rapid filtration through UniFilter-96 plates (PerkinElmer), pre-soaked for at least $2 \mathrm{~h}$ in polyethylenimine (PEI) 0.6\%, and using a MicroMate 96 Cell Harvester (PerkinElmer). The tubes and filters were then washed five times with $0.5 \mathrm{~mL}$ aliquots of Tris buffer $(50 \mathrm{mM}, \mathrm{pH} 7.4$, $\left.4^{\circ} \mathrm{C}\right)$. Filters were dried and soaked in Microscint 40 (PerkinElmer), and bound radioactivity was counted by a TopCount Microplate Scintillation Counter (PerkinElmer).

\section{Analysis of pharmacological data}

All values in the text, tables or figures are mean and 95\% confidence limits ( $95 \%$ c.l.), or mean \pm SEM of the given number of experiments.

Binding data were fitted by using GraphPad Prism 4.0 in order to determine the equilibrium dissociation constant $\left(\mathrm{K}_{\mathrm{d}}\right)$ from homologous competition experiments, the ligand concentration inhibiting the radioligand binding of the 50\% $\left(\mathrm{IC}_{50}\right)$ from heterologous competition experiments. $\mathrm{K}_{\mathrm{i}}$ values were calculated from $\mathrm{IC}_{50}$ using the Cheng-Prusoff equation $\left(\mathrm{K}_{\mathrm{i}}=\mathrm{IC}_{50} /\left(1+\right.\right.$ [radioligand] $\left./ \mathrm{K}_{\mathrm{d}}\right)$ according to the concentration and $\mathrm{K}_{\mathrm{d}}$ of the used radioligand (Cheng and Prusoff, 1973). $B_{\max }$ values were expressed as $\left[{ }^{3} \mathrm{H}\right]-\mathrm{BK}$ specifically bound as fmol. $\mathrm{mg}^{-1}$ of protein.

Concentration-response curves in functional experiments were analysed by sigmoidal non-linear regression fit using the GraphPad Prism 4.0 program (San Diego, CA, USA) to determine the molar concentration of the agonist producing the $50 \%\left(E_{50}\right)$ of its maximal effect $\left(\mathrm{E}_{\max }\right)$. Agonist responses obtained either in the absence (control) or presence of antagonist were normalized towards the $\mathrm{E}_{\max }$ of control agonist response. The antagonist potency was quantified as $\mathrm{pA}_{2}$ values, defined as the molar concentration of antagonist that produces a twofold shift to the right of the agonist concentration-response curve, as follows: $\mathrm{pA}_{2}=\log [\mathrm{CR}-1]-$ $\log$ [antagonist concentration], where CR is the ratio of equiactive concentrations of agonist in the presence and absence of antagonist (Kenakin, 1997).

\section{Modelling}

The human $\mathrm{B}_{2}$ receptor model was obtained as previously described (Meini et al., 2002; 2004). Briefly, the starting point was the crystallographic structure of bovine rhodopsin receptor (Palczewski et al., 2000), further refined taking into account the recent crystal structure of the $\beta_{2}$-adrenoceptor (Cherezov et al., 2007; Rasmussen et al., 2007; Rosenbaum et al., 2007). Residues were mutated according to the proper human $B_{2}$ receptor sequence (Hess et al., 1992) and their side chains positions refined. Then an analysis was performed on receptor amino acid residues within the TM segments, and presumed facing inward, by means of the GRID program (Molecular Discovery Ltd, London, UK) with water, hydrophobic and amphyphilic probes, thus defining lipophilic pockets: a larger one among the TM helices 3, 4, 5 and 6 , and a smaller one among the TM helices 2, 3 and 7. These two pockets were considered and evaluated as potential binding sites for MEN16132. Only the largest pocket would allow a 
meaningful docking of MEN16132. A manual docking was then applied to a relaxed conformation of the ligand, using Tripos Sybyl software (v. 8.0 Tripos, St. Louis, MO, USA). The docking was based on the results from the mutational analyses, with some slight adjustment of bond torsions to fit the best orientation of the ligand.

\section{Materials}

$\left[{ }^{3} \mathrm{H}\right]-\mathrm{BK}$ (specific activity $90 \mathrm{Ci} \cdot \mathrm{mmol}^{-1}$ ) and myo- $\left[1,2-{ }^{3} \mathrm{H}\right]$ inositol (specific activity $60-80 \mathrm{Ci} \cdot \mathrm{mmol}^{-1}$ ) were provided by Perkin Elmer, and $\left[{ }^{3} \mathrm{H}\right]-\mathrm{MEN} 11270$ (specific activity $\left.30 \mathrm{Ci} \cdot \mathrm{mmol}^{-1}\right) \quad$ (H-DArg-Arg-Pro-Hyp-Gly-Thi-c(Dab-DTicOic-Arg)c(7 $\gamma-10 \alpha)$; Meini et al. 1999) was synthesized by SibTech Inc. (Newington, CT, USA). The peptide $\mathrm{B}_{2}$ receptor agonist BK was obtained from PolyPeptide (Strasbourg, France). DL-2-mercaptomethyl-3-guanidoethylthiopropanoic acid (MERGETPA) was from Merck (Darmstadt, Germany), whereas all other enzyme inhibitors and salts were from Sigma (Dorset, UK). MEN16132 ((4-(S)-amino5 - (4 - \{4 - [2,4-dichloro-3-(2,4-dimethyl-8-quinolyloxymethyl) phenylsulfonamido] - tetrahydro - $2 \mathrm{H}$ - 4 - pyranylcarbonyl piperazino)-5-oxopentyl](trimethyl) ammonium chloride hydrochloride), MEN15880, MEN16298, MEN16303, MEN16318 (structures in Table 1) and icatibant (DArg[Hyp ${ }^{3}$, $\left.\left.\mathrm{Thi}^{5}, \mathrm{DTic}^{7}, \mathrm{Oic}^{8}\right] \mathrm{BK}\right)$ were synthesized in Menarini Ricerche, dissolved in distilled water at $10 \mathrm{mM}$ and stored at $-25^{\circ} \mathrm{C}$, and further dilutions were made in the appropriate assay buffer.
The non-peptide $B_{2}$ receptor agonist FR190997 (8-[2,6dichloro-3-[(N-(E)-4-(N-methylcarbamoyl)cinnamidoacetyl]$\mathrm{N}$-methylamino] benzyloxy)-2-methyl-4-(2-pyridylmethoxy) quinoline, Aramori et al. 1997), kindly provided by Fujisawa company (now Astellas), was dissolved in DMSO up to a concentration of $100 \mu \mathrm{M}$.

\section{Results}

MEN16132 and icatibant affinity for $\left[{ }^{3} \mathrm{H}\right]-\mathrm{BK}$ specifically bound to the recombinant and endogenously expressed human $B_{2}$ receptor

The affinity of MEN16132 and icatibant was assessed at the recombinant and endogenously expressed human $\mathrm{B}_{2}$ receptor by using $\left[{ }^{3} \mathrm{H}\right]-\mathrm{BK}$ as radioligand and membranes prepared from $\mathrm{CHO}$ cells stably expressing the human $\mathrm{B}_{2}$ receptor and human fibroblast-like synoviocytes (Figure 1) respectively. Homologous displacement of BK gave $\mathrm{K}_{\mathrm{d}}$ values of $0.16 \mathrm{nM}$ (0.095-0.28, 95\% c.1.) and $0.20 \mathrm{nM}(0.11-0.35,95 \%$ c.l.) with membranes of $\mathrm{CHO}$ cells and synoviocytes respectively. $\mathrm{B}_{\max }$ values were $322 \pm 14$ and $553 \pm 51 \mathrm{fmol} \cdot \mathrm{mg}^{-1}$ proteins in $\mathrm{CHO}$ and synovial cells respectively $(n=3)$.

Both antagonists totally inhibited the $\left[{ }^{3} \mathrm{H}\right]-\mathrm{BK}$ specific binding in a concentration-dependent manner, and the resulting inhibition curves were overlapping in both cell membrane systems. From experiments performed with $\mathrm{CHO}$

\section{Table 1}

Comparison of icatibant and MEN16132 affinity at wild type and mutant human $B_{2}$ receptors (hB $\left.B_{2} R\right)$

\begin{tabular}{|c|c|c|c|c|c|}
\hline$h B_{2} R$ & TM & $\begin{array}{l}\text { MEN16132 } \\
K_{i}[n M](95 \% \text { CI) }\end{array}$ & $\begin{array}{l}{\left[{ }^{3} \mathrm{H}\right] \text {-bra }} \\
\text { F }_{\text {mut }}\end{array}$ & $\begin{array}{l}\text { Iding } \\
\text { Icatibant } \\
\mathrm{K}_{\mathrm{i}} \text { [nM] }(95 \% \mathrm{CI})\end{array}$ & $\mathbf{F}_{\text {mut }}$ \\
\hline Wild type & & $0.09(0.07-0.10)$ & 1 & $0.08(0.07-0.09)$ & 1 \\
\hline E47A & 1 & $0.15(0.12-0.18)$ & 1.6 & $0.19(0.16-0.25)$ & 2.4 \\
\hline I110A & 3 & $28(19-41)$ & 311 & $0.25(0.22-0.39)$ & 3.1 \\
\hline S111A & 3 & $0.11(0.085-0.14)$ & 1.2 & $0.16(0.09-0.31)$ & 2 \\
\hline L114A & 3 & $0.10(0.09-0.11)$ & 1.1 & $0.11(0.08-0.13)$ & 1.4 \\
\hline S117A & 3 & $0.15(0.11-0.20)$ & 1.7 & $0.19(0.14-0.23)$ & 2.3 \\
\hline $\mathrm{T} 158 \mathrm{~A}$ & 4 & $0.09(0.075-0.11)$ & 1 & $0.12(0.06-0.22)$ & 1.5 \\
\hline L166F & 4 & $0.11(0.09-0.14)$ & 1.2 & $0.15(0.12-0.20)$ & 1.8 \\
\hline F252A & 6 & $0.18(0.15-0.23)$ & 2 & $0.02(0.01-0.05)$ & 0.2 \\
\hline W256A & 6 & $0.44(0.37-0.51)$ & 5 & $0.16(0.14-0.20)$ & 2 \\
\hline Q288A & 7 & $0.15(0.10-0.21)$ & 1.7 & $0.25(0.19-0.40)$ & 3.1 \\
\hline F292A & 7 & $0.22(0.17-0.29)$ & 2.4 & $0.11(0.12-0.25)$ & 1.4 \\
\hline Y295F & 7 & $9.0(7.9-10.5)$ & 100 & $0.39(0.31-0.51)$ & 4.9 \\
\hline Y295A & 7 & $68(56-83)$ & 755 & $0.15(0.06-0.38)$ & 1.9 \\
\hline Y295W & 7 & $2.7(2.4-3.5)$ & 30 & $0.07(0.04-0.15)$ & 0.9 \\
\hline W256A/Y295F & $6 / 7$ & 151 (116-197) & 1670 & $0.35(0.17-0.71)$ & 4.4 \\
\hline
\end{tabular}

The affinity was evaluated at the peptide agonist $\left[{ }^{3} \mathrm{H}\right]$-bradykinin radioligand binding site. $\mathrm{F}_{\text {mut }}$ index was calculated as $\mathrm{K}_{\mathrm{i}}$ (mutant receptor)/ $\mathrm{K}_{\mathrm{i}}$ (wild type receptor), and corresponds to fold decrease in affinity. $F_{\text {mut }}$ indexes greater than 3 are shown in bold type. TM indicates the transmembrane portion of the receptor where the mutated amino acid residue is located. Data are from three independent experiments, each one performed in duplicate. $K_{i}$ values measured for MEN16132 were previously presented (Cucchi et al., 2005). 


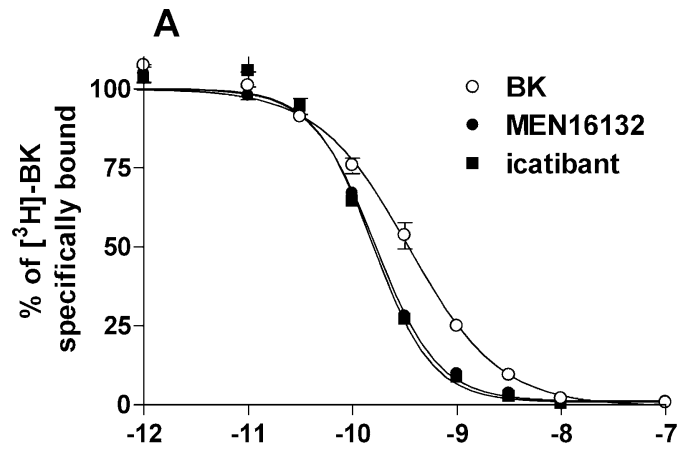

B

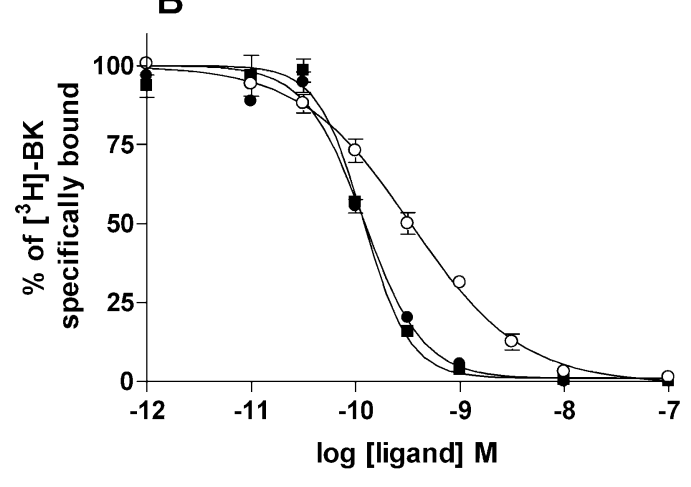

\section{Figure 1}

MEN16132 and icatibant affinity at the $\left[{ }^{3} \mathrm{H}\right]$-bradykinin (BK) binding site in $\mathrm{CHO}$ cells expressing the human $\mathrm{B}_{2}$ receptor $(A)$ and in human fibroblast-like synovial cells (B).

cell membranes the calculated $K_{\mathrm{i}}$ values were $0.087 \mathrm{nM}$ (0.078-0.092, 95\% c.l.) for MEN16132 and $0.081 \mathrm{nM}(0.071-$ $0.092,95 \%$ c.l.) for icatibant (Figure 1A), and from those performed with synoviocyte membranes, $\mathrm{K}_{\mathrm{i}}$ values were $0.067 \mathrm{nM}(0.059-0.076$, 95\% c.l.) for MEN16132 and $0.066 \mathrm{nM}(0.058-0.075,95 \%$ c.l.) for icatibant (Figure 1B).

\section{Reversibility pattern of $B_{2}$ receptor functional blockade exerted by MEN16132 and icatibant in $\mathrm{CHO}$ cells expressing the human $\mathrm{B}_{2}$ receptor and in human synovial cells}

The reversibility of MEN16132 and icatibant from receptor compartment was investigated in $\mathrm{CHO}$ cells expressing the human $\mathrm{B}_{2}$ receptor and in human synovial cells.

Agonist responses obtained with antagonist-treated cells were expressed as a percentage of the time-matched control response, that is, BK-induced IP response obtained in cells not treated with antagonists and that were given the same number of washing cycles.

In both assays cells were preincubated for $15 \mathrm{~min}$ with different concentrations of antagonists which inhibited the BK (3 nM) induced IP accumulation.

In CHO cells, MEN16132 at $1 \mathrm{nM}$ concentration inhibited the BK-induced IP accumulation by 53\%, whereas at higher concentrations $(10,100 \mathrm{nM}$ and $1 \mu \mathrm{M}$, Figure $2 \mathrm{~A})$ it produced a complete inhibition (time 0 ). Then the agonist response was evaluated after washing with drug-free medium, which was

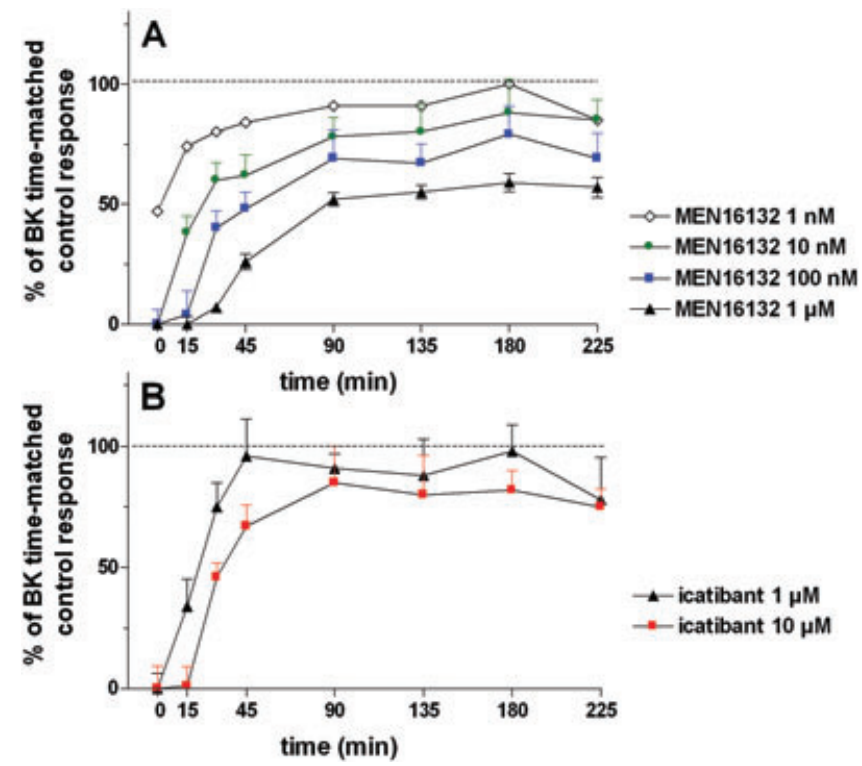

Figure 2

Reversibility of kinin $B_{2}$ receptor blockade induced by MEN16132 (A) and icatibant (B) in the inositol phosphate accumulation assay performed in $\mathrm{CHO}$ cells stably expressing the human recombinant $\mathrm{B}_{2}$ receptor. Cells were incubated for $15 \mathrm{~min}$ with antagonists at $37^{\circ} \mathrm{C}$ at the indicated concentrations, and then responses to bradykinin (BK) ( $3 \mathrm{nM}$ incubated for $60 \mathrm{~min}$ ) were obtained, immediately or after different periods during which the medium was renewed every $15 \mathrm{~min}$. Data are expressed as per cent control time-matched responses (100\%), and are shown as mean \pm SEM of 3-5 experiments, each one performed in triplicate.

renewed every $15 \mathrm{~min}$ (wash period) along a period of $3 \mathrm{~h}$ and $45 \mathrm{~min}$ (a longer time could not be used because of the significant decay of BK control response under the present experimental settings in both cell assays). The rate of recovery of BK functional response in cells pre-exposed to MEN16132 was dependent on the concentration of antagonist used (Figure 2A). Icatibant was used at two concentrations, 1 and $10 \mu \mathrm{M}$, which both blocked the BK-induced IP accumulation (time 0 , Figure 2B), and the time-course of the functional BK response recovery was faster than that obtained with MEN16132.

As at the higher concentrations of MEN16132 used, the recovery of BK response was not complete (Figure 2A), a further set of experiments was performed to confirm that by increasing the number of washes it was possible to obtain a greater recovery of agonist functional response. Thus the effect on the reversibility of functional blockade was checked by pretreating $\mathrm{CHO}$ cells with $100 \mathrm{nM}$ MEN16132 and comparing $15 \mathrm{~min}$ versus $5 \mathrm{~min}$ washing periods. After $90 \mathrm{~min}$ the $\mathrm{BK}$ response was $58 \pm 5 \%$ and $87 \pm 4 \%$ of time-matched control responses (cells which were not pretreated with the antagonist but that were exposed to the same washing protocol) respectively (data not shown).

Similar data were obtained with synovial cells (Figure 3). The inhibition exerted by icatibant was quickly reversed. At $1 \mu \mathrm{M}$ antagonist concentration, the BK response after three washing periods $(45 \mathrm{~min})$ was $90 \pm 3 \%$ of time-matched 
control response, and at $10 \mu \mathrm{M}$ antagonist concentration it was $97 \pm 16$ after six washing periods $(90 \mathrm{~min})$. On the contrary, MEN16132 antagonism was reversed more slowly. After 15 washing periods ( $3 \mathrm{~h}$ and $45 \mathrm{~min}$, as limit time of the experiment, see above) the BK response was $98 \pm 9 \%, 86 \pm$ $4 \%$ and $53 \pm 5 \%$ of the time-matched controls in cell pretreated with $10 \mathrm{nM}, 100 \mathrm{nM}$ and $1 \mu \mathrm{M}$ MEN16132 concentration.

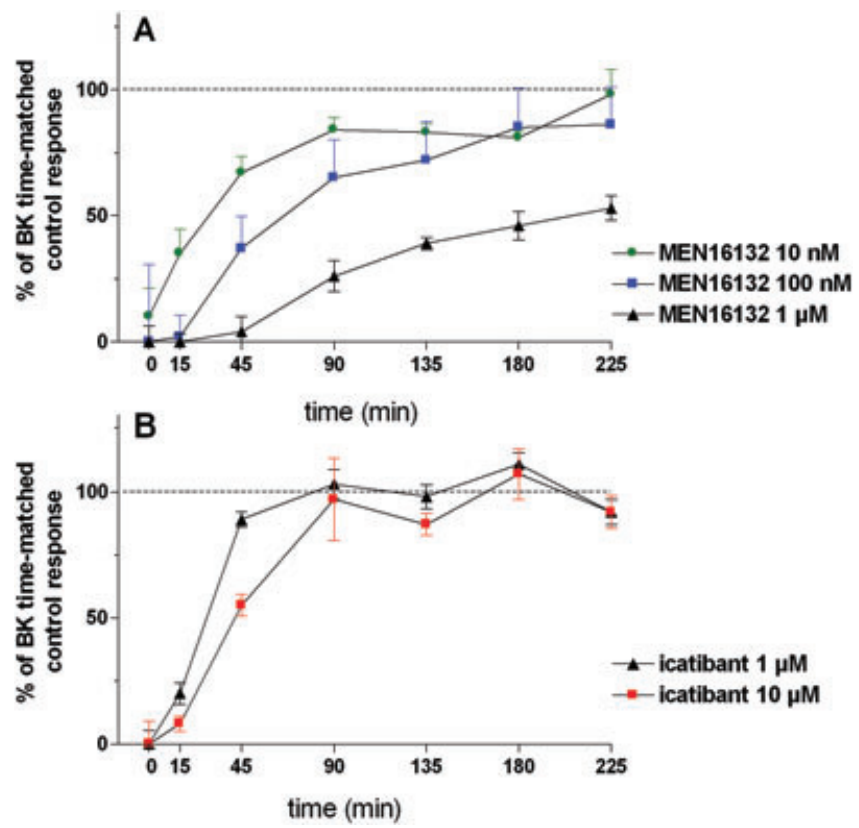

\section{Figure 3}

Reversibility of kinin $B_{2}$ receptor blockade induced by MEN16132 (A) and icatibant (B) in the inositol phosphate accumulation assay performed in human fibroblast-like synovial cells. Cells were incubated for 15 min with antagonists at $37^{\circ} \mathrm{C}$ as described under Methods, and then responses to bradykinin (BK) ( $3 \mathrm{nM}$ incubated for $60 \mathrm{~min}$ ) were obtained, immediately or after different periods during which the medium was renewed every $15 \mathrm{~min}$. Data are expressed as per cent control time-matched responses (100\%), and are shown as mean \pm SEM of 3-5 experiments, each one performed in triplicate.

\section{Icatibant affinity is not affected by point-mutations which impair the} affinity of MEN16132

The affinity of icatibant was determined with 17 selected point-mutated human $\mathrm{B}_{2}$ receptors previously used to characterize the profile of MEN16132 (Cucchi et al., 2005). All the selected mutations were localized in the TM segments of the $B_{2}$ receptor sequence. Inhibition curves to icatibant were performed at the radiolabelled agonist $\left[{ }^{3} \mathrm{H}\right]-\mathrm{BK}$ (Table 1 ) or antagonist $\left[{ }^{3} \mathrm{H}\right]-\mathrm{MEN} 11270$ (Table 2) binding site. This tritiated antagonist was used on those mutations which abolished the binding of BK (W86A and F259A, Meini et al., 2002).

No differences in icatibant affinity could be observed at most of the mutated residues, even those which impaired the binding affinity of MEN16132 (Cucchi et al., 2005). The only mutations which decreased icatibant affinity by three to fivefold were I110A (TM3), Y295F (TM7) and the double mutant W256A/Y295F (TM6/7) (Table 1).

\section{Molecular model of the human $B_{2}$ receptor and MEN16132 complex}

Experiments were performed to define the receptor regions corresponding to the tetrahydropyranyl and the quaternary ammonium groups which were considered to favour the high antagonist potency of MEN16132.

First, the affinity of MEN16132 was compared to that of a series of derivatives differing in the $\alpha, \alpha$-disubstituted amino acid, as indicated in Table 3 . These compounds were evaluated by their inhibition of the antagonist $\left[{ }^{3} \mathrm{H}\right]-\mathrm{MEN} 11270$ binding site at the wild type and W86A mutated $\mathrm{B}_{2}$ receptors. In this set of experiments, the affinity of MEN16132 was decreased by 1782-fold at the mutant receptor as compared with the wild type, again indicating a strong involvement of the W86 residue in the MEN16132 interaction. The rank order of $\mathrm{F}_{\text {mut }}$ indexes (Table 3) indicated a stronger interaction by structures which display a more extended lipophilic character and the capability to form hydrogen bond. Inhibition curves are shown in Figure 4 and highlight that the differences found at the wild type receptor (Figure 4A) are indeed flattened by the W86A mutation (Figure 4B).

In a second set of experiments the antagonist potency of MEN16132 was tested in the IP accumulation assay

\section{Table 2}

Comparison of icatibant and MEN16132 affinity at wild type and mutant human $\mathrm{B}_{2}$ receptors $\left(h \mathrm{~B}_{2} \mathrm{R}\right)$

\begin{tabular}{|c|c|c|c|c|c|}
\hline$h B_{2} R$ & TM & $\begin{array}{l}\text { MEN16132 } \\
\mathrm{K}_{\mathrm{i}}[\mathrm{nM}](95 \% \mathrm{Cl})\end{array}$ & $\begin{array}{l}{\left[{ }^{3} \mathrm{H}\right]-\mathrm{ME}} \\
\mathrm{F}_{\text {mut }}\end{array}$ & $\begin{array}{l}\text { Iding } \\
\text { Icatibant } \\
\mathbf{K}_{\mathbf{i}}[\mathbf{n M}](95 \% \mathrm{Cl})\end{array}$ & $\mathbf{F}_{\text {mut }}$ \\
\hline wild type & & $0.6(0.4-0.8)$ & 1 & $0.28(0.17-0.50)$ & 1 \\
\hline W86A & 2 & $717(450-1140)$ & 1195 & $0.79(0.47-1.05)$ & 2.8 \\
\hline F259A & 6 & $0.3(0.2-0.5)$ & 0.5 & $0.19(0.15-0.32)$ & 0.7 \\
\hline
\end{tabular}

The affinity was evaluated at the peptide antagonist $\left[{ }^{3} \mathrm{H}\right]-\mathrm{MEN} 11270$ radioligand binding site. $\mathrm{F}_{\text {mut }}$ index was calculated as $\mathrm{K}_{\mathrm{i}}$ (mutant receptor) $/ \mathrm{K}_{\mathrm{i}}$ (wild type receptor), and corresponds to fold decrease in affinity. $\mathrm{F}_{\text {mut }}$ indexes greater than 3 are shown in bold type. TM indicates the transmembrane portion of the receptor where is located the mutated amino acid residue. Data are from three independent experiments, each one performed in duplicate. $\mathrm{K}_{\mathrm{i}}$ values measured for MEN16132 were previously presented (Cucchi et al., 2005). 
Table 3

Comparison of affinity of MEN16132 and a series of derivatives substituted in the place of the tetrahydropyranyl group (X) at the wild type and W86A mutant human $\mathrm{B}_{2}$ receptor<smiles>[X]NC(=O)N1CCN(C(=O)[C@H](N)CCC[N+](C)(C)C)CC1</smiles>

\begin{tabular}{|c|c|c|c|c|c|}
\hline Compound & i.d. compound' & $\mathbf{x}$ & $K_{i}$ wild type (nM) & $\mathrm{K}_{\mathrm{i}}$ W86A mutant (nM) & $F_{\text {mut }}$ \\
\hline MEN16132 & 72 & & $0.4(0.3-0.6)$ & $713(340-1500)$ & 1782 \\
\hline MEN15880 & 63 & & $1(0.7-1.3)$ & $650(330-1320)$ & 650 \\
\hline MEN16318 & 70 & & $12(8-20)$ & $2860(750-5000)$ & 238 \\
\hline MEN16298 & 68 & & $3.4(1.8-6.3)$ & $808(330-1975)$ & 237 \\
\hline MEN16303 & 69 & & $13(11-16)$ & $525(200-2400)$ & 40 \\
\hline
\end{tabular}

$\mathrm{F}_{\text {mut }}$ index was calculated as $\mathrm{K}_{\mathrm{i}}$ (mutant receptor)/ $\mathrm{K}_{\mathrm{i}}$ (wild type receptor), and corresponds to fold decrease in affinity.

${ }^{1}$ Compound i.d. from Fattori et al. (2007).

performed at the wild type in comparison with the double mutant D266A/D284A B 2 receptor. Since this mutation abolished the binding of the peptide agonist (BK) and peptide antagonists (both MEN11270 and icatibant) (Bellucci et al., 2004), the antagonist potency was evaluated towards the functional responses induced by the non-peptide $\mathrm{B}_{2}$ receptor agonist FR190997, whose pharmacological profile is not affected by this mutation. In the present experiments, FR190997 induced IP accumulation with similar potency at the wild type and $\mathrm{D} 266 \mathrm{~A} / \mathrm{D} 284 \mathrm{~A} \mathrm{~B}_{2}$ receptor, $\mathrm{EC}_{50}$ values being $0.94 \mathrm{nM}(0.82-1.07,95 \%$ c.1.) and 0.57 (0.48-0.68, 95\% c.l.) respectively. MEN16132 antagonist behaviour was evaluated towards the agonist concentration-response curve (Figure 5), and at $1 \mathrm{nM}$ concentration it shifted the agonist curve obtained in the cells expressing the wild type receptor by 4.7 -fold, and by 2.1-fold in the D266A/D284A mutant, which yielded $\mathrm{pA}_{2}$ values of 9.57 and 9.04 respectively. At $10 \mathrm{nM}$ antagonist concentration, the calculated $\mathrm{pA}_{2}$ values were 9.42 and 9.10 in the cells expressing the wild type receptor and the D266A/D284A mutant $B_{2}$ receptor respectively. This difference was minor when MEN16132 was tested at $100 \mathrm{nM}$ concentration, such as the calculated $\mathrm{pA}_{2}$ values were 9.03 in the cells expressing the wild type and 8.88 in those expressing the mutant $\mathrm{B}_{2}$ receptor. On the contrary, with this latter antagonist concentration a significant difference was evident when comparing the maximal agonist effect obtained in the presence of MEN16132 in the cells expressing the wild type $(62 \pm 3 \%)$ with that obtained in the cells 

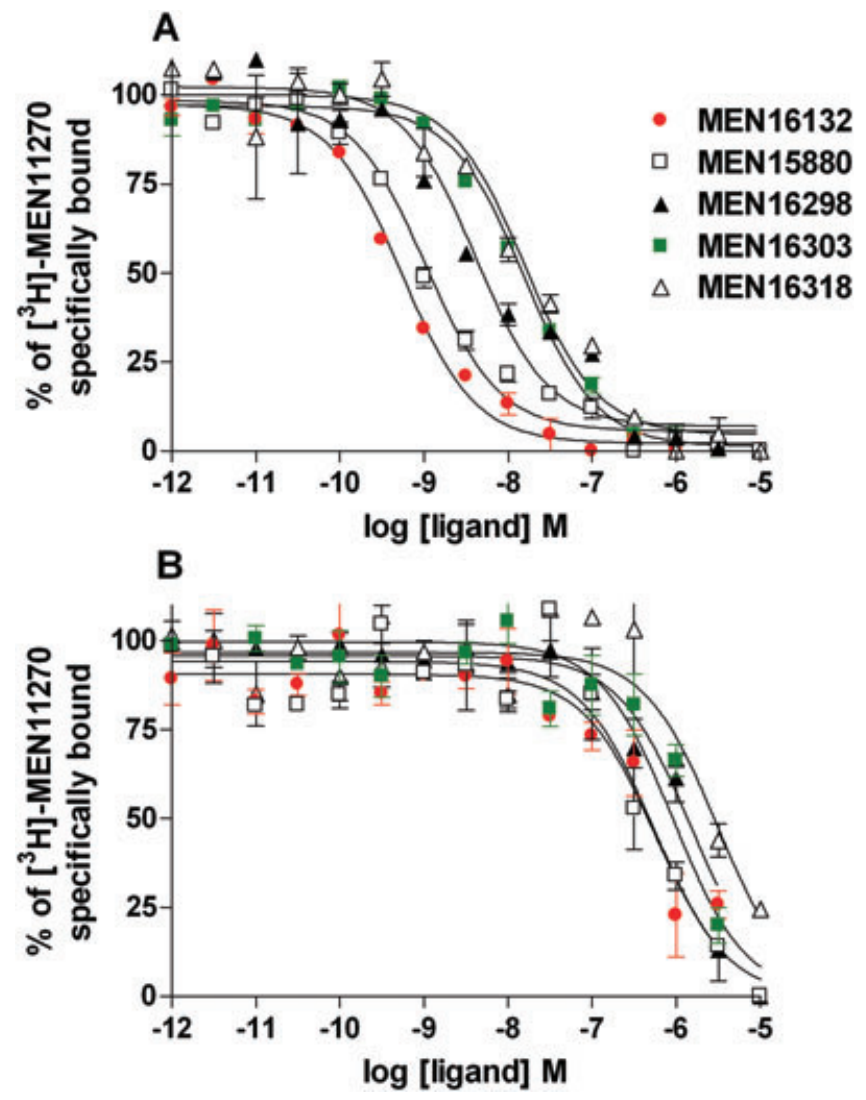

\section{Figure 4}

Competition binding curves of MEN16132 and a series of its derivatives at the peptide antagonist $\left(\left[{ }^{3} \mathrm{H}\right]-\mathrm{MEN} 11270\right)$ specifically bound to the wild type (A) and W86A mutant (B) human $B_{2}$ receptor. Compound structures and their affinity values are reported in Table 3.

expressing the D266A/D284A mutant $\mathrm{B}_{2}$ receptor $(80 \pm 2 \%)$, which indicated a greater insurmountable antagonist effect at the wild type than at the mutant receptor.

\section{Discussion}

The present pharmacological analysis shows that the different pharmacodynamic properties displayed by the two kinin $\mathrm{B}_{2}$ receptor antagonists MEN16132 and icatibant are based on a different reversibility, that is, rate of loss from the receptor compartment where they exert the functional blockade of BK responses, and on their different recognition sites in the human $\mathrm{B}_{2}$ receptor.

Previous studies performed at the recombinant $(\mathrm{CHO}$ cells) and native (human lung fibroblasts, HLF-1) human $B_{2}$ receptor in membrane preparation assays indicated similar binding affinity values towards the radiolabelled agonist binding site for MEN16132 and icatibant $\left(\mathrm{pK}_{\mathrm{i}}\right.$ values in the range 10.1-10.6; Cucchi et al., 2005). On the other hand, MEN16132 was about 60 -fold more potent than icatibant in antagonizing BK-mediated IP stimulation both in $\mathrm{CHO}$ cells expressing the human $\mathrm{B}_{2}$ receptor $\left(\mathrm{pK}_{\mathrm{B}}\right.$ values 10.3 and 8.5 for
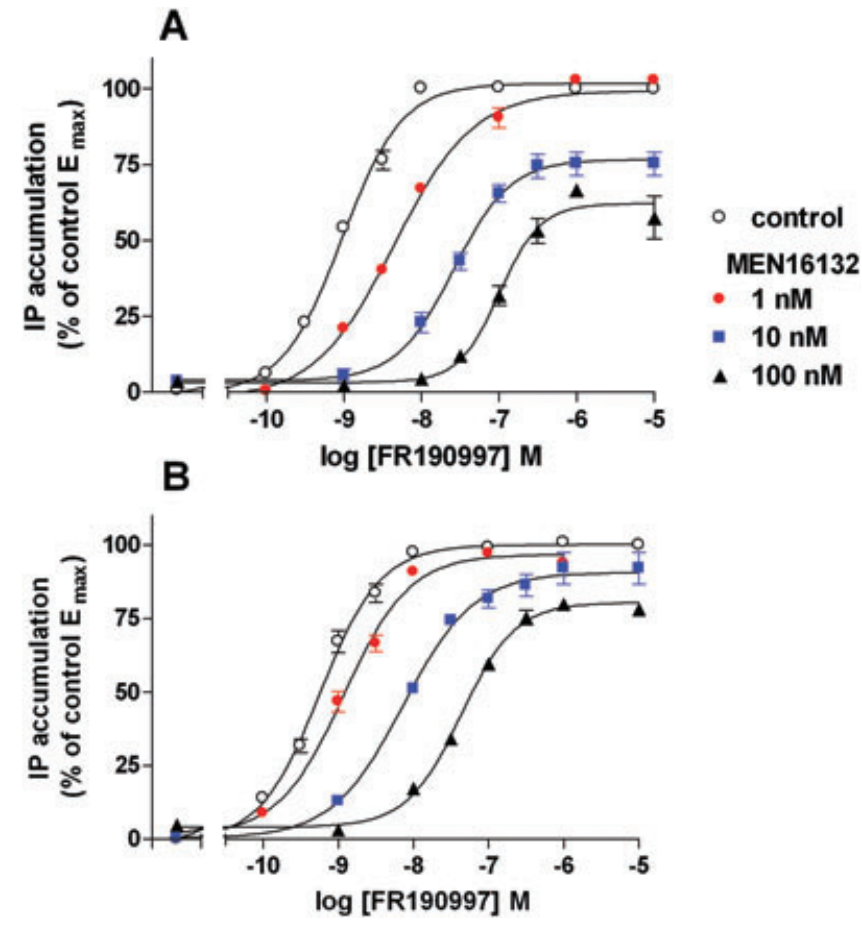

Figure 5

MEN16132 antagonism of inositol phosphate (IP) accumulation induced by the $B_{2}$ receptor non-peptide agonist FR190997 at the wild type $(A)$ and double mutated D266A/D284A (B) human $B_{2}$ receptor expressed in $\mathrm{CHO}$ cells.

MEN16132 and icatibant respectively; Bellucci et al., 2004; Cucchi et al., 2005) and in human fibroblast-like synoviocytes $\left(\mathrm{pK}_{\mathrm{B}}\right.$ values 9.9 and 8.1 for MEN16132 and icatibant respectively; Bellucci et al., 2009). Thus, we first checked the similar affinity of MEN16132 and icatibant at the BK binding site in membranes of both $\mathrm{CHO}$ and synovial fibroblasts, under the same experimental settings, as previous data obtained with the latter cell model were obtained in cultured cells $\left(\mathrm{pK}_{\mathrm{i}} 8.9\right.$ and 8.4 for MEN16132 and icatibant respectively; Bellucci et al., 2009). Then the kinetics of the $B_{2}$ receptor blockade exerted by the two antagonists was estimated by using a functional experimental approach. The time-course of reversibility of $B_{2}$ receptor blockade was evaluated through washout experiments in the IP accumulation assay in both $\mathrm{CHO}$ cells and human synovial cells. Data presented here indicate that MEN16132 dissociates from the receptor compartment more slowly than icatibant, when the two antagonists are evaluated at the same concentration. Alternatively, it can be conceived that a concentration of icatibant two orders of magnitude greater than that of MEN16132 is necessary to obtain the same time-course of functional recovery from $\mathrm{B}_{2}$ receptor blockade, and this supports their difference in antagonist potency (estimated as $\mathrm{pK}_{\mathrm{B}}$ values, as reported above). Present findings agree with those previously obtained in a different assay (rat uterus contractility, Meini et al., 2009).

In the second part of this investigation the characterization of the two $B_{2}$ receptor antagonists at 17 mutant receptors is presented, in order to confirm that the two compounds 
interact at different levels in the receptor membrane portion. Amongst the mutant receptors investigated, only the I110A, Y295F and W256A/Y295F mutations modestly decreased the affinity of icatibant. Contrary to what observed at the rat and human kinin $B_{2}$ receptor by Jarnagin et al. (1996) and Marie et al. (2001) who investigated the binding profile of icatibant by using the radiolabelled antagonist, we found a decrease in affinity of this antagonist only with the Y295F mutant (but not with the Y295A). Different reasons may be responsible for this divergent results, including the fact that, in this study, the affinity is measured at the radiolabelled agonist binding site, and the fact that these mutations per se affect the recognition site of BK, so that both affinity or efficacy are altered (Bellucci et al., 2003). Indeed it is difficult to attribute meaningful causes at the modest reductions in affinity observed for icatibant from presented data (three to fivefold), whilst it can be inferred that the binding interaction of this antagonist with the kinin $B_{2}$ receptor is not hampered by any of the mutations which indeed decreased the affinity of MEN16132 (Cucchi et al., 2005), and that the two antagonists recognize the receptor protein at different levels.

The last part of this investigation aimed at producing a model of MEN16132 docked to the human $\mathrm{B}_{2}$ receptor. Using mutagenesis of the human $\mathrm{B}_{2}$ receptor, we previously presented data on the essential role of the quinoline moiety of non-peptide antagonists and its interaction with some residues belonging to TM3, TM6 and TM7 (Meini et al., 2004), which together define a lipophilic receptor binding crevice in a part of the receptor involved in the balance of active/ inactive protein conformers, either for the human $\mathrm{B}_{2}$ receptor or other GPCRs (Gether and Kobilka, 1998; Marie et al., 2001; Rosenbaum et al., 2009). In this study, our efforts are focused on finding specific receptor counterparts for the other pharmacophores of MEN16132, such as the tetrahydropyranyl and the quaternary ammonium groups, which were known to be important for high affinity ligand-receptor interaction from structure-activity relationship studies (Fattori et al., 2006; 2007). The W86 residue was identified as being involved both in the binding interaction of agonist and other non-peptide antagonists besides MEN16132 (Meini et al., 2002; Bellucci et al., 2003), but not peptide antagonists such as icatibant or MEN11270 (this study; Meini et al., 2002). The hypothesis that this functional group lies close to the W86 residue in the upper portion of TM2, which is involved in agonist receptor activation, can account for the potent antagonist properties of MEN16132. A series of derivatives bearing different groups in the place of the tetrahydropyranyl group (present in the MEN16132 structure) were assessed in displacing the radiolabelled peptide antagonist MEN11270 bound to the wild type and to the W86A mutant. The results obtained at the wild type receptor indicate (Figure 4 and Table 3) that indeed the ligand-receptor interaction is favoured (higher affinity) by the compound bearing the tetrahydropyranyl group (MEN16132) which can have a lipophilic interaction with the aromatic ring of W86. This interaction can also be stabilized by a hydrogen bond interaction between the oxygen of the tetrahydropyranyl group and the basic nitrogen of the W86 receptor residue (Figure 6). This high affinity interaction is then progressively diminished by groups which maintain lipophilic properties but do not have the capability to form a hydrogen bond (cyclopen-

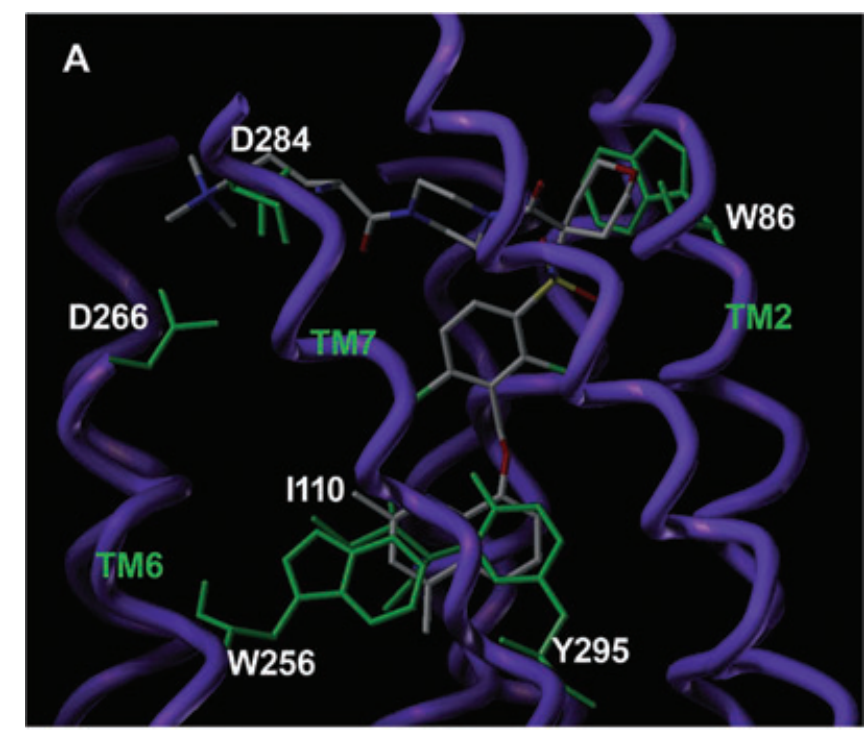

B D284 (TM7)

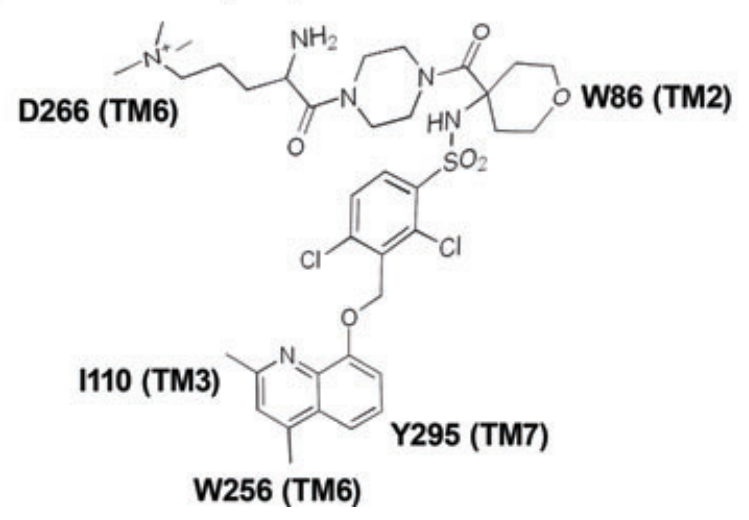

Figure 6

Model of the $B_{2}$ receptor antagonist MEN16132 docked at the human $B_{2}$ receptor, as viewed from the transmembrane side $(A)$ and schematic representation of the putative ligand-receptor interactions (B). The quinoline group lies in a binding pocket comprised between 1110 (TM3), W256 (TM6) and Y295 (TM7), and with this latter residue forms both a hydrogen bond (between the nitrogen of the quinoline group and the hydroxyl function of Tyr residue) and an aromatic-aromatic interaction. The tetrahydropyran ring engages with W86 (TM2) through lipophilic (aromatic-aromatic) and hydrogen bond (between the oxygen of the tetrahydropyran group and the nitrogen of Trp residue) interactions, whereas the positively charged quaternary ammonium of MEN16132 forms a salt bridge with the two aspartic acid residues, D266 (at the top of TM6) and D284 (top of TM7).

tyl and tetrahydrothiopyranyl groups, i.e. MEN15880 and MEN16298 respectively) or groups that bear protonated or basic amines (N-methylpiperidyl and piperidyl groups, i.e. MEN16318 and MEN16303 respectively). The fact that these observed differences among the different derivatives are not any longer evident in the W86A mutant suggested to us that the substituted group (tetrahydropyranyl group) was involved in the interaction with the tryptophan residue in TM2 (W86). 
The two aspartic acid residues located at the top of TM6 and TM7, D266 and D284, respectively, appear to be in close proximity and may serve as receptor counterpart for an electrostatic interaction with a basic function. Indeed an interaction between these receptor residues and the basic arginine located in the N-terminal end of peptide ligands, both agonist and antagonists, had already been indicated both at the human and the rat $\mathrm{B}_{2}$ receptor (Novotny et al., 1994; Kyle, 1995; Jarnagin et al., 1996; Bellucci et al., 2004). Using the IP accumulation assay and the $\mathrm{B}_{2}$ receptor activation induced by the non-peptide agonist FR190997, we have already demonstrated the strong interaction of icatibant with the D266 and D284 residues (Bellucci et al., 2004), which displayed a $\mathrm{pA}_{2}$ value of 8.2 at the wild type and 6.5 at the D266A/D284A mutant receptor. Present data obtained from the wild type receptor cell system indicate that MEN16132 displays an even higher antagonist potency also towards the $\mathrm{B}_{2}$ receptor activation mediated by the non-peptide agonist FR190997 ( $\mathrm{pA}_{2}$ 9.1-9.6). We consider the reduction of potency and the minor insurmountable antagonist behaviour observed with MEN16132 at the D266A/D284A $\mathrm{B}_{2}$ receptor mutant, as indicative of an interaction of these residues with the basic quaternary ammonium group, previously shown to contribute to the high antagonist potency of this compound (Fattori et al., 2006; 2007) (Figure 6). The difference observed at the mutant D266A/D284A receptor is not as great as that previously observed with icatibant (see above), and we consider that this is due to the buried interaction of MEN16132 within the TM receptor region provided by TM3, 6 and 7 (see above) and to the fact that FR190997 interacts with some residues (i.e. I110, Y295) which are also part of the MEN16132 recognition site (Bellucci et al., 2003).

As a whole, the present investigation indicates that MEN16132 has a slower reversibility than icatibant from the $\mathrm{B}_{2}$ receptor compartment, and supports the concept that the residence time of the drug molecule on its molecular target may contribute to its long-lasting efficacy in vivo (Copeland et al., 2006; Vauquelin and Van Liefde, 2006), and in particular for the longer duration of action of MEN16132 versus icatibant previously shown in in vivo animal models (Valenti et al., 2008; Cialdai et al., 2009). Moreover, our present findings represent an example of pharmacological assays supporting the molecular modelling, and indicate that the MEN16132 recognition site is located in the TM portion of the human kinin $\mathrm{B}_{2}$ receptor, and involves residues contributing to receptor activation.

\section{Acknowledgement}

The Authors wish to thank Astellas for kindly providing the kinin $\mathrm{B}_{2}$ receptor agonist FR190997.

\section{Conflict of interest}

None.

\section{References}

Alexander SPH, Mathie A, Peters JA (2009). Guide to Receptors and Channels (GRAC). Br J Pharmacol 158: S1-S254.

Aramori I, Zenkoh J, Morikawa N, Asano M, Hatori C, Sawai H et al. (1997). Nonpeptide mimic of bradykinin with long-acting properties at the bradykinin $\mathrm{B}_{2}$ receptor. Molec Pharmacol 52: 16-20.

Bellucci F, Meini S, Cucchi P, Catalani C, Reichert W, Zappitelli S et al. (2003). A different molecular interaction of bradykinin and the synthetic agonist FR190997 with the human $\mathrm{B}_{2}$ receptor: evidence from mutational analysis. Br J Pharmacol 140: 500-506.

Bellucci F, Meini S, Cucchi P, Catalani C, Giuliani S, Zappitelli S et al. (2004). The N-terminal of icatibant and bradykinin interact with the same Asp residues in the human $\mathrm{B}_{2}$ receptor. Eur J Pharmacol 491: 121-125.

Bellucci F, Cucchi P, Catalani C, Giuliani S, Meini S, Maggi CA (2009). Novel effects mediated by bradykinin and pharmacological characterization of $\mathrm{B}_{2}$ receptor antagonism in human synovial fibroblasts. Br J Pharmacol 158: 1996-2004.

Bond AP, Breipohl G, Worthy K, Campion G, Dieppe PA, Bhoola KD (1992). Metabolism and characterisation of kinins and Hoe 140 (kinin antagonist) in the synovial fluid of patients with inflammatory joint diseases. Agents Actions Suppl 38: 582-589.

Cheng Y, Prusoff WH (1973). Relationship between the inhibition constant $\left(\mathrm{K}_{1}\right)$ and the concentration of inhibitor which causes 50 per cent inhibition $\left(\mathrm{I}_{50}\right)$ of an enzymatic reaction. Biochem Pharmacol 22: 3099-3108.

Cherezov V, Rosenbaum DM, Hanson MA, Rasmussen SG, Thian FS, Kobilka TS et al. (2007). High-resolution crystal structure of an engineered human beta2-adrenergic $G$ protein-coupled receptor. Science 318: 1258-1265.

Cialdai C, Giuliani S, Valenti C, Tramontana M, Maggi CA (2009). Effect of intra-articular MEN16132, a kinin $B_{2}$ receptor antagonist, on nociceptive response in monosodium iodoacetate-induced experimental osteoarthritis in rats. J Pharmacol Exp Ther 331: 1025-1032.

Copeland RA, Pompliano DL, Meek TD (2006). Drug-target residence time and its implications for lead optimization. Nat Rev Drug Discov 5: 730-739.

Cucchi P, Meini S, Bressan A, Catalani C, Bellucci F, Santicioli P et al. (2005). MEN16132, a novel potent and selective nonpeptide antagonist for the human bradykinin $\mathrm{B}_{2}$ receptor. In vitro pharmacology and molecular characterization. Eur J Pharmacol 528: 7-16.

Dziadulewicz EK (2005). Non-peptide ligands for bradykinin receptors 1995-2004. Expert Opin Ther Patent 15: 829-859.

Fattori D, Rossi C, Fincham CI, Berettoni M, Calvani F, Catrambone F et al. (2006). Design and synthesis of novel sulfonamide-containing bradykinin $\mathrm{hB}_{2}$ receptor antagonists. 1 . Synthesis and SAR of alpha,alpha-dimethylglycine sulfonamides. J Med Chem 49: 3602-3613.

Fattori D, Rossi C, Fincham CI, Caciagli V, Catrambone F, D'Andrea P et al. (2007). Design and synthesis of novel sulfonamide-containing bradykinin $\mathrm{hB}_{2}$ receptor antagonists. 2 . Synthesis and structure-activity relationships of alpha,alpha-cycloalkylglycine sulfonamides. J Med Chem 50: 550-565.

Fincham CI, Bressan A, Paris M, Rossi C, Fattori D (2009). Bradykinin receptor antagonists - a review of the patent literature 2005-2008. Expert Opin Ther Pat 19: 919-941. 
Gether U, Kobilka BK (1998). G Protein-coupled receptors. II. Mechanism of agonist activation. J Biol Chem 273: 17979-17982.

Hess JF, Borkowski JA, Young GS, Strader CD, Ransom RW (1992). Cloning and pharmacological characterization of a human bradykinin (BK-2) receptor. Biochem Biophys Res Comm 184: 260-268.

Hock FJ, Wirth K, Albus U, Linz W, Gerhards HJ, Wiemer G et al. (1991). Hoe 140 a new potent and long acting bradykinin-antagonist: in vitro studies. Br J Pharmacol 102: 769-773.

Jarnagin K, Bhakta S, Zuppan P, Yee C, Ho T, Phan T et al. (1996). Mutations in the $\mathrm{B}_{2}$ bradykinin receptor reveal a different pattern of contacts for peptidic agonists and peptidic antagonists. J Biol Chem 271: 28277-28286.

Kenakin TP (1997). Competitive antagonism. In: Kenakin TP (ed.). Pharmacologic Analysis of Drug-Receptor Interaction, 3rd edn. Lippincott Williams \& Wilkins: Philadelphia, PA, pp. 331-373

Kyle DJ (1995). Structure-based drug design: progress toward the discovery of the elusive bradykinin receptor antagonists. Curr Pharm Design 1: 233-254.

Leeb-Lundberg LM, Marceau F, Muller-Esterl W, Pettibone DJ, Zuraw BL (2005). International union of pharmacology. XLV. Classification of the kinin receptor family: from molecular mechanisms to pathophysiological consequences. Pharmacol Rev 57: 27-77

Legat FJ, Griesbacher T, Lembeck F (1994). Mediation by bradykinin of rat paw oedema induced by collagenase from Clostridium histolyticum. Br J Pharmacol 112: 453-460.

Marie J, Richard E, Pruneau D, Paquet J-L, Siatka C, Larguier R et al. (2001). Control of conformational equilibria in the human $B_{2}$ bradykinin receptor. J Biol Chem 276: 41100-41111.

Meini S, Quartara L, Rizzi A, Patacchini R, Cucchi P, Giolitti A et al. (1999). MEN11270, a novel selective constrained peptide antagonist with high affinity at the human $\mathrm{B}_{2}$ kinin receptor. J Pharmacol Exp Ther 289: 1250-1256.

Meini S, Cucchi P, Zappitelli S, Rotondaro L, Quartara L, Giolitti A et al. (2002). Preliminary mutational analysis of the human kinin $\mathrm{B}_{2}$ receptor for nonpeptide antagonist ligands recognition. Can J Physiol Pharmacol 80: 303-309.

Meini S, Cucchi P, Bellucci F, Catalani C, Faiella A, Rotondaro L et al. (2004). Site-directed mutagenesis at the human $\mathrm{B}_{2}$ receptor and molecular modelling to define the pharmacophore of non-peptide bradykinin receptor antagonists. Biochem Pharmacol 67: 601-609.
Meini S, Cucchi P, Bellucci F, Catalani C, Giuliani S, Santicioli P et al. (2007). Comparative antagonist pharmacology at the native mouse bradykinin $\mathrm{B}_{2}$ receptor: radioligand binding and smooth muscle contractility studies. Br J Pharmacol 150: 313-320.

Meini S, Cucchi P, Catalani C, Bellucci F, Giuliani S, Santicioli P et al. (2009). Pharmacological characterization of the bradykinin $B_{2}$ receptor antagonist MEN16132 in rat in vitro bioassays. Eur J Pharmacol 615: 10-16

Meini S, Cucchi P, Catalani C, Bellucci F, Santicioli P, Giuliani S et al. (2010). Radioligand binding characterization of the bradykinin $\mathrm{B}_{2}$ receptor in the rabbit and pig ileal smooth muscle. Eur J Pharmacol 635: 34-39.

Novotny EA, Bednar DL, Connolly MA, Connor JR, Stormann TM (1994). Mutation of aspartate residues in the third extracellular loop of the rat $\mathrm{B}_{2}$ bradykinin receptor decrease affinity for bradykinin. Biochem Biophys Res Commun 201: 523-530.

Palczewski K, Kumasaka T, Hori T, Behnke CA, Motoshima H, Fox BA et al. (2000). Crystal structure of rhodopsin: A G protein-coupled receptor. Science 289: 739-745.

Rasmussen SG, Choi HJ, Rosenbaum DM, Kobilka TS, Thian FS Edwards PC et al. (2007). Crystal structure of the human beta2 adrenergic G-protein-coupled receptor. Nature 450: 383-387.

Regoli D, Barabé J (1980). Pharmacology of bradykinin and related kinins. Pharmacol Rev 32: 1-46.

Rosenbaum DM, Cherezov V, Hanson MA, Rasmussen SG, Thian FS, Kobilka TS et al. (2007). GPCR engineering yields high-resolution structural insights into beta2-adrenergic receptor function. Science 318: 1266-1273.

Rosenbaum DM, Rasmussen SG, Kobilka BK (2009). The structure and function of G-protein-coupled receptors. Nature 459: 356-363.

Valenti C, Cialdai C, Giuliani S, Lecci A, Tramontana M, Meini S et al. (2005). MEN16132, a novel potent and selective nonpeptide kinin $\mathrm{B}_{2}$ receptor antagonist: in vivo activity on bradykinin-induced bronchoconstriction and nasal mucosa microvascular leakage in anesthetized guinea pigs. J Pharmacol Exp Ther 315: 616-623.

Valenti C, Cialdai C, Giuliani S, Tramontana M, Quartara L, Maggi CA (2008). MEN16132, a kinin $B_{2}$ receptor antagonist, prevents the endogenous bradykinin effects in guinea-pig airways. Eur J Pharmacol 579: 350-356.

Vauquelin G, Van Liefde I (2006). Slow antagonist dissociation and long-lasting in vivo receptor protection. Trends Pharmacol Sci 27: 355-359.

Wirth K, Hock FJ, Albus U, Linz W, Alpermann HG, Anagnostopoulos H et al. (1991). Hoe 140 a new potent and long acting bradykinin-antagonist: in vivo studies. Br J Pharmacol 102: $774-777$. 